\title{
Fighting Insurgency, Ruining the Environment: the Case of Forest Fires in the Dersim Province of Turkey
}

\author{
Pinar Dinc $^{1}$ (D) $\cdot$ Lina Eklund $^{1} \cdot$ Aiman Shahpurwala $^{2} \cdot$ Ali Mansourian $^{3} \cdot$ Augustus Aturinde $^{3,4} \cdot$ Petter Pilesjö $^{3}$
}

Accepted: 12 June 2021 / Published online: 11 July 2021

(C) The Author(s) 2021

\begin{abstract}
Environmental destruction has long been used as a military strategy in times of conflict. A long-term example of environmental destruction in a conflict zone can be found in Dersim/Tunceli province, located in Eastern Turkey. In the last century, at least two military operations negatively impacted Dersim's population and environment: 1937-38 and 1993-94. Both conflict and environmental destruction in the region continued after the 1990s. Particularly after July 2015, when the brief peace process that began in 2013 ended, conflict between the Turkish state and the Kurdistan Workers' Party (PKK) resumed and questions arose about the cause of forest fires in Dersim. In this research we investigate whether there is a relationship between conflict and forest fires in Dersim. This is denied by the Turkish state but asserted by many Dersim residents, civil society groups, and political parties. We use a multi-disciplinary approach, combining methods of qualitative analysis of print media (newspapers), social media (Twitter), and local accounts, together with quantitative methods: remote sensing and spatial analysis. Interdisciplinary analysis combining quantitative datasets with in-depth, qualitative data allows a better understanding of the role of conflict in potentially exacerbating the frequency and severity of forest fires. Although we cannot determine the cause of the fires, the results of our statistical analysis suggest a significant relationship between fires and conflict in Dersim, indicating that the incidence of conflicts is generally correlated with the number of fires.
\end{abstract}

Keywords Forest fires $\cdot$ Armed conflict $\cdot$ Environmental damage $\cdot$ Remote sensing $\cdot$ Kurds $\cdot$ PKK $\cdot$ Dersim/Tunceli $\cdot$ Turkey

\section{Introduction}

Environmental destruction has long been used as a military tactic in times of conflict. In the 1950s, the British Army used herbicides in Southeast Asia against Malayan guerrillas and a decade later, United States military forces used Agent Orange, a powerful herbicide, in Vietnam to destroy forest cover as well as food crops of the North Vietnamese and Viet Cong troops (Martini 2013; Nguyen 2009). The Virunga Volcanoes area in Africa, a UN World Heritage Site, has been destroyed by the conflicts

Pinar Dinc

pinar.dinc@cme.lu.se

1 Department of Physical Geography and Ecosystem Science, Lund University and Centre for Advanced Middle Eastern Studies, Lund University, P.O. Box 117, 22100 Lund, Sweden

2 Seattle, USA

3 GIS Centre, Department of Physical Geography and Ecosystem Science, Lund University, P.O. Box 117, 22100 Lund, Sweden

4 Department of Lands and Architectural Studies, Kyambogo University, Kampala, Uganda between Rwanda and the Democratic Republic of Congo. In all these cases, forests were viewed as shelter and food sources (i.e., by the local community, rebel groups, or guerrilla fighters) and therefore targeted (Hough 2014; Austin and Bruch 2000).

A long-lasting example of environmental destruction in a conflict zone can be found in Dersim/Tunceli, ${ }^{1}$ a province located in Eastern Turkey. Dersim has been a zone of conflict for centuries, because of its semi-autonomous position and Alevi identity under the Sunni-dominated Ottoman Empire and its Kurdish, Kirmanc and/or Zaza identity (Bruinessen 1997; Kehl-Bodrogi 1999; Sözen 2019; Dinç 2020) under the Turkish Republic that has been implementing policies towards ethnic and cultural homogeneity of the newly established nationstate. Consequently, there have been numerous military operations in the region, conducted by both the Ottoman and Turkish armies, leading to thousands of civilian deaths, forced displacement, as well as the destruction (mainly via burning) of forests,

\footnotetext{
${ }^{1}$ Although the province was officially renamed Tunceli in 1936, Dersim is still widely used locally. Throughout the paper, we refer to the province as Dersim, except instances where we use maps, official names (e.g., the Tunceli Law, the Tunceli governor), or where the cited sources refer to the province as Tunceli.
} 
agricultural fields, and villages (Bulut 2013; Bilmez et al. 2011; Algör 2010). The events in 1937-38 are referred to as tertele in the native language, which means being upside down, implying devastation across individual, societal, and environmental dimensions, connotating to genocide.

There have been studies on the environmental damage caused by this conflict in the 1990s (Etten et al. 2008; Jongerden et al. 2007). The socio-ecological devastation caused by the military operations against the PKK in Dersim in 1993-94 is referred to as "the Second 38". Both conflict and environmental destruction in the region continued after the 1990s. Questions arose about forest fires in Dersim, particularly after July 2015, when the brief peace process that began in 2013 came to an end and conflict between the state and the PKK resumed. The issue was not confined to local politics - questions surrounding the causes of the forest fires erupting in the Kurdish regions in Turkey, and particularly Dersim, were also raised in the European Parliament (Question for written answer E-005396/2018 2020).

With temperatures rising globally and more extreme weather expected in the study area, it is important to disentangle the effects of climate on the occurrence of forest fires in Dersim. In light of the environmental destruction in previous conflict periods (1930s and 1990s), local residents primarily link the increase in the frequency of forest fires with the activities of the state, which they accuse of setting forests on fire either directly through military exercises or indirectly by not extinguishing fires that spontaneously erupt. Such a linkage is persistently denied by the Turkish state. Given this background, our aim in this research is to investigate whether there is a relationship between conflicts and forest fires in Dersim. To answer this question, we specifically focus on the four years after 2015, following the end of the peace process between Turkey and the PKK.

Our research is based on a multi-disciplinary approach, in which we combine qualitative and quantitative methods to provide a better understanding of the relationship between conflict and forest fires in Dersim. In doing so, we use different datasets (i.e., conflicts, fires) and spatial analysis to determine where, when, and how fires (co-)occur in space and time alongside other factors such as military conflict. Although it is difficult - if not impossible - to answer from this analysis why these fires occurred and who was responsible, discourse analysis of the narratives around forest fires during periods of conflict allows us to trace the contrasting accounts of the links between forest fires and conflict in Dersim.

\section{Dersim as a Conflict Zone - 1938, 1994, and 2015 Onwards}

Dersim, located within the eastern part of Turkey (Fig. 1), has been a zone of conflict - both spatially and politically - since the late 1800s (Goner 2017; Çalışlar 2010).
Various official reports on Dersim during the late-Ottoman period, in 1896, 1899, 1903, and 1906 (Yildiz 2014; Bulut 2013), described Dersim as a rebellious or criminal place that failed to recognize central authority. These reports were often followed by military operations, termed "disciplining operations," also known as "flood operations" in the early 1900s. The Republic of Turkey (hereafter Turkey) was established in 1923 , and from the late 1920s onwards, reports were also produced on how to "modernise" or "civilise" Dersim, a region that was labelled as backward, tribal, rebellious, and increasingly under the threat of "Kurdification" in the eyes of the state (Y1ldiz 2014).

In December 1935, the Turkish Parliament introduced the Tunceli Law, altering the borders of the Dersim region and renaming the province Tunceli. The Law on the Administration of Tunceli Province, passed on 4 January 1936, was also a declaration of a state of emergency in the province and endorsed the Fourth General Inspector, Abdullah Alpdoğan, as the governor of the province with full authority. Following two years of building infrastructure, such as roads, bridges, and police stations in Dersim, Turkey launched its first military operation in 1937, mainly targeting tribal leaders (Alpkaya 1988). Despite the surrender and execution of seven key tribal figures in Dersim, the Council of Ministers in May 1937 decided to continue the operations with a "forceful attack against Western-Central Dersim, to kill all who used or had used arms and to remove the population settled between Nazimiye and Sin [districts of Dersim]" (Keiser 2011). In 1938, villages were raided, houses were burned down, nearly 14,000 Dersimlis were killed, and around 12,000 Dersimlis were exiled to the western provinces of Turkey. ${ }^{2}$ Furthermore, children over the age of five were sent to Turkish-language boarding schools to encourage identification with the Republic. Young girls were separated from their families and adopted for indoctrination and conversion to Sunni Islam. Dersim was declared a forbidden zone for 10 years, until the 1948 Amnesty allowed deported Dersimlis to return to their homeland (Deniz 2020). The 1937-38 operation, which was officially called "the discipline and banishment operation" (tedip ve tenkil harekati), can be seen as a state act of genocide (tertele), ${ }^{3}$ which traumatised post-genocide society over subsequent decades.

From the 1970s onwards, Dersim has been a stronghold of insurgent movements. TIKKKO (The Communist Party of

\footnotetext{
${ }^{2}$ According to the official documents of the Gendarmerie General Commandership, which then Prime Minister Erdogan shared in November 2011, 13,800 people were killed in Dersim in between 1936 and 1939, and around 11,600 people were exiled to western Turkey (Al Jazeera 2011). Today, these numbers are considered official.

${ }^{3}$ In 1977, İsmail Beșikçi was the first scholar to define Dersim 1937-38 as a state act of genocide (Beșikçi 2013). Mark Levene's two-volume book on genocide also refers to Dersim as a "partial and local" genocide (Levene 2005: 203). For a more recent account of Dersim 1938 as an act of genocide, see Deniz 2020.
} 


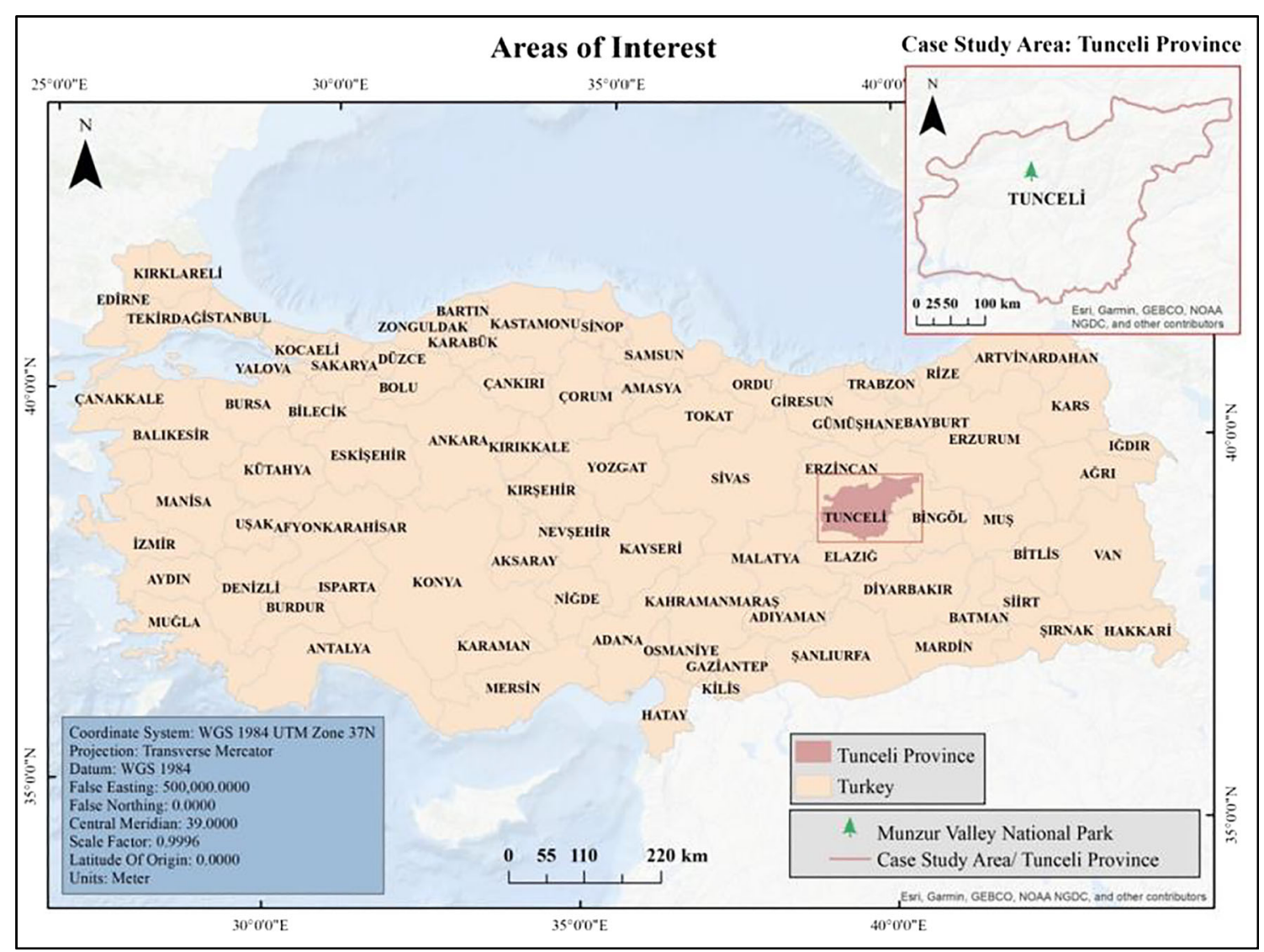

Fig. 1 Tunceli (Dersim) Province is the case study area, highlighted within the Republic of Turkey (Source: Shahpurwala 2019)

Turkey/Marxist-Leninist) has been a powerful armed group in the region since its establishment in 1972. Despite the 1980 military coup that shattered leftist parties and organisations in Turkey, the PKK, which was established in 1978, launched a war against the Turkish state in 1984, leading to the declaration of a state of emergency on 19 July 1987, effectively imposed in Kurdish dominated parts of eastern and southeastern Turkey (often referred to as Turkey's Kurdistan, or Bakur in Kurdish), such as Bingöl, Diyarbakır, Elazığ, Hakkari, Mardin, Siirt, Van, and Dersim. The State of Emergency Regional Government was established, which appointed governors with extraordinary authorities to the region. Despite these measures, the armed groups (mainly the PKK and TIKKO) managed to continue their guerrilla activities in the region. Jongerden et al. (2007) note that in 1992, the PKK could confidently take its troops into the Ovacik district of Dersim even during the daytime. From 1993 onwards, however, the Turkish Armed Forces (TAF) changed its strategy with the PKK and shifted from the "defensive and static position" towards a "field domination doctrine" (Jongerden 2007: 67). The TAF nearly doubled its number of troops in the field and increased the number of 'village guards' to 70,000 (Jongerden 2007: 68). In 1994, the Turkish government launched military operations in Dersim, setting forests and villages on fire and forcing villagers to evacuate, leaving their homes, fields, and cattle behind (Taş 2007). Forest burning resulted in burning $7.5 \%$ of the forests and $26.6 \%$ of the forests near villages in Dersim during 1993 94 (Jongerden 2007: 13).

In February 1999, the PKK leader Abdullah Öcalan was captured in Kenya and brought to Turkey, where he remains in solitary confinement in İmralı Prison. During this time, Öcalan began criticising statist and patriarchal "capitalist modernity" and proposed "democratic modernity" that relies on "democratic confederalism," a model based on ethnic, cultural, and political diversity (Öcalan 2011; Dinc 2020). At the same time the Justice and Development Party (AKP) government began implementing certain reforms in its Europeanisation process. Aras and Polat (2008) argue that this process fostered 'de-securitisation.' Ünal (2016: 92) also describes the de-securitisation process as Turkey's recognition of "the costly deadlock of the conflict" and its move towards a "conciliatory approach" to solve the Kurdish issue.

The signals of such a conciliatory approach began with backchannel communications in 2005 , leading to a process called the Oslo Talks that took place between 2008 and 2011 (Dicle 2017). Through the end of 2012, talks between the PKK and the Turkish government were re-initiated with 
the İmralı process. ${ }^{4}$ The process eventually failed in the summer of 2015 for reasons ranging from the absence of a proper mechanism of conflict resolution (Baser and Ozerdem 2019; Jongerden 2019; Çiçek 2018) to points of disagreement on the practical and legal actions to be taken by both parties and the role of international politics, namely the Rojava revolution in Northern Syria (Çiçek 2018; Kaya and Whiting 2017).

With the abrupt end of the peace process in 2015, conflict has escalated throughout Turkey, which has been particularly destructive for the Kurdish populations as well as the environment. Using data from the Turkish Statistical Institute, the Ministry of Environment and Forestry, and the Ministry of Agriculture and Village Affairs, Gurses (2012: 255-256) argues that "civil war increases deforestation and leads to a substantial decline in animal production," and also observes that forests are easy to destroy "en masse via chemicals or fire" and that they are "easy targets" for government forces. We explore the fire patterns in Dersim in the context of political instability with a multi-disciplinary approach, combining natural and social science methods.

\section{Methods}

We focus on fires and conflict in Dersim as a single case study, covering the period from 2003 onwards, but in particular on 2015-2018. We draw on a multi-disciplinary approach, combining quantitative methods (remote sensing and spatial analysis) with qualitative analysis of print media (newspapers), social media (Twitter), and local accounts.

\section{Qualitative Assessment}

We began our qualitative assessment by determining key concepts, dates, actors, and institutions, and pinpointing particular districts/villages subject to forest fires in Dersim. We relied on our background knowledge of the region, supported by an initial review of newspaper coverage and social media posts as well as conflict and fire data we collected from local informants. Based on this information, which we confirmed with satellite-based fire data for Dersim, we focused on the month of August in the years between 2015 and 2018 in our qualitative analysis. We conducted a content analysis of eight different newspapers representing different political viewpoints (i.e., mainstream, right-wing, pro-government, Kemalist, left-wing, pro-Kurdish): Sabah, Sözcü, Hürriyet, Cumhuriyet, Birgün, Evrensel, Özgür Gündem and Özgür Yaşam for August of 2015-2018. We examined all relevant content (i.e., news reports, photographic representations, and opinion columns) in the aftermath of the peace process,

\footnotetext{
${ }^{4}$ Imralı is the name of the island in the Marmara Sea on which Öcalan is imprisoned.
}

entered the data in Excel, and created word clouds with the headlines of the news pieces using the nVivo content analysis software.

In addition to content analysis of selected newspapers, we examined posts on Twitter, focusing on the same period. Tweets were extracted from Twitter's Advanced Search using Python between June 2015 and September 2018 with the GetOldTweets 3 library (https://pypi.org/project/ GetOldTweets3/). We used several hashtags such as \#DersimYaniyor [Dersim is on fire], \#Dersim Yakiliyor [Dersim is set on fire], \#DersimeSesVer [Give voice to Dersim], \#DersimeSesOl [Be the voice for Dersim], \#DersimeSuOl [B e water for Dersim], \#DersimeBirDamlaSuOl [Be a drop of water for Dersim], and \#TunceliYaniyor [Tunceli is on fire]. Since many of these hashtags were often used together, we pre-processed the data by deleting duplicate tweets and retweets, as well as using the Natural Language Toolkit (NLTK) library on Python (https://pypi.org/project/nltk/), which removed any unnecessary punctuation and Turkish stopwords (i.e., "bu", "ve", "ya", "filan"). Stop words are filtered out because they do not carry important meaning in a sentence for analysis. We then created word clouds using the pre-processed data. We used the collections library (https://docs.python.org/3/library/ collections.html) to count each of the meaningful words in the tweets and generate a notepad with word counts using Python. We then uploaded this notepad into the https://wordart.com/ website to produce the word clouds.

Although we did not conduct in-depth interviews, we were able to trace local people's accounts from various sources. We had personal communications in 2019 with 15 local people and activists from/in Dersim, some of whom lived in the areas affected by forest fires after 2015. We did not record interviews or the names of contacts to protect their personal data. We included four reports on forest fires in Dersim published by different institutions: The Peoples' Democratic Party [Halklarin Demokratik Partisi, HDP] (HDP Report 2015), the Democratic Society Congress [Demokratik Toplum Kongresi, DTK] (DTK Report 2015), the Republican People's Party [Cumhuriyet Halk Partisi, CHP] (CHP Report 2015), and the Centre for Dersim Studies [Dersim Araştırmaları Merkezi, DAM] (DAM Report 2019), some of which include testimonies from local people. Finally, we included statements issued by the Tunceli Governorship published in 2017 and 2018 (Basın Açılaması 2017, 2018).

\section{Quantitative Assessment}

We used the quantitative data to explore the statistical relationship between the number of fires in Dersim in recent years and the prevalence of political instability and conflict within Turkey. The data used in this quantitative assessment measure the frequency of fires and conflicts for the period between 
2003 and 2019, under the AKP governments. Fluctuations in political stability and conflict are represented by the number of reported conflicts within Turkey, while the number of fires is derived from remote sensing data, which describe daily thermal anomalies indicative of fires, day or night, on a global scale. These data are produced at a $1 \mathrm{~km}$ spatial resolution by NASA's Moderate Resolution Imaging Spectroradiometer (MODIS) Active Fire (AF) product (v. 6). The data product was determined to be reliable in a global accuracy assessment by Giglio et al. (2016). The data are available on the Global Fire Emissions Database https://www.globalfiredata.org/, an open-source spatial database.

The conflict data are available from the Uppsala Conflict Data Program (UCDP) (Sundberg and Melander 2013), an open-source program for providing standardised data on conflict events. A conflict event is defined as an instance of organised violence with at least one fatality. The conflict data are mined from sources such as newspapers, governmental and non-governmental organization (NGO) reports, case studies, and historical archives (ibid.). The conflict data are also geo-referenced, with coordinate locations obtained from sources such as the GEOnet Names Server database or maps provided by various NGOs. We then ran the data through a series of checks for quality and consistency between data sources. The resulting conflict data provide the frequency and spatial distribution of conflicts, which we filtered to include only conflict events occurring in Turkey.

There are some limitations in the data that mainly concern the regional accuracy of the fire data (Giglio et al. 2016) and the possible underreporting of conflicts (Sundberg and Melander 2013). First, the ability of MODIS AF to detect all fires in the Middle East region is, according to Giglio et al. (2016), lower than in the other regions of the world (a 7\% detection probability vs $26 \%$ in Australia and New Zealand), while the false alarm rate is around $2 \%$. So far from all fires will have been detected, but the false detection rate of fires is low. The main reason for such errors is the size of the fires, with small fires more likely to be undetected (Giglio et al. 2016). We decided to use the MODIS AF product with this limitation in mind because it provides a longer period of data than other fire products. There may also be errors related to underreporting in the UCDP. According to Sundberg and Melander (2013), the UCDP is limited by strict theoretical definitions of what constitutes a "conflict event." UCDP requires organised activities by identifiable actors and does not include armed conflict during semiorganised activities, such as riots, protests, or demonstrations, which also influence the political atmosphere in Turkey. However, since most of the conflict data observed in this study are between the PKK and the Turkish state, the results provide a good understanding of the conflict dynamics and political context of the war.
With these limitations in mind, we still find that our results provide important information that helps us better understand the narratives about conflict and fire in Dersim. We use our resulting data to understand how trends in fire occurrences in Dersim correspond to the ongoing narratives.

Using the conflict and fire data, we carried out statistical testing to understand their potential relationship. It should be noted that any such relationship does not imply causality, but rather that conflict and fires tend to occur at the same time and place. We used the Spearman-Rank statistical test to understand the relationship using hypothesis and significance testing (Spearman 1904). The test is rank-based and measures the magnitude of correlation based on the average ranks. The magnitude of the correlation describes the degree to which the number of fires within Dersim and the number of reported conflicts within Turkey increase and decrease simultaneously.

To aid the analysis of the interplay between conflicts and fires at a finer scale, we divided the study area into $5 \mathrm{~km}$ by $5 \mathrm{~km}$ grid cells and carried out a Bivariate Local Moran's Index (BiLISA) analysis. We used the BiLISA analysis to investigate simultaneous occurrence in both conflicts and fires by analysing the correlation between one variable (e.g., fires) at a given location, defined by a grid cell, and a second variable (e.g., conflicts) in adjacent locations, defined by the corresponding and neighbouring grid cells. It reports areas with hotspots (High-High, i.e., both variables have high values), cold spots (Low-Low, i.e., both variables have low values), and discordant (High-Low or Low-High) clusters. We counted the fires and conflicts falling within each cell for the periods before the peace process (2003-2014) and after the peace process failed (2015-2019) to observe differences or similarities in the spatial relationships between the two periods. To ensure the robustness of the obtained clusters, we used 9999 randomisations for this analysis.

Finally, we used the Google Earth Engine to extract data from the TerraClimate dataset (Abatzoglou et al. 2018), for Tunceli/Dersim province, to include the effects of climate variability in the analysis. TerraClimate provides monthly data on climate and climatic water balance, with a spatial resolution of approximately $4 \mathrm{~km}$ and covering the period 1958-2019 (updated annually). We used the Palmer Severity Drought Index (PDSI) product, a standardised index that estimates relative dryness (Dai et al. 2019). The values range between -10 (dry) and 10 (wet), and values below -3 are considered severe to extreme drought. From the monthly data, we calculated mean PDSI values for each year and also extracted data for August - generally the month with the highest fire frequency. 


\section{Competing Narratives and a Quantitative Assessment of Conflict and Fires in Dersim}

The assessment of the news coverage, social media posts, and reports published by different institutions, including local testimonies, reveals competing accounts of the correlation between forest fires and conflict in Dersim (Dinç 2020b). The content analysis of newspapers indicates that there is a noteworthy variance among media outlets' coverage of the subject, which is arguably shaped by the political viewpoints they represent. While mainstream (Hürriyet), right-wing, antigovernment Kemalist (Sözcü), and/or pro-government (Sabah) media hardly even mentioned forest fires in Dersim, left-wing Kemalist (Cumhuriyet), left-wing (Evrensel, Birgün), and left-wing and pro-Kurdish (Özgür Gündem and Yeni Yaşam) media outlets reported news pieces on forest fires in Dersim.

Özgür Gündem/Yeni Yaşam ${ }^{5}$ and Evrensel were the key newspapers that consistently reported forest fires in Dersim (Fig. 2). There were no news reports on the forest fires in the right-wing newspapers Sabah and Sözcü, even though the former is pro-government and the latter is anti-government. In Hürriyet there were only two articles concerning the fires in 2017: one reported forest fires in "six different areas in Tunceli," while the other was an interview conducted with the Dersim deputy Gürsel Erol, who said that the state could not be blamed for conducting a military operation in its struggle for "public order and public authority" and therefore nobody has the right to object to it. However, Erol continued, the state should also take responsibility for extinguishing these fires. Sabah took a similar approach by publishing news articles about the fight against the "terrorists" in Dersim who attacked the military. These accounts indicate the "official approach" of the state, which has either ignored the forest fires or viewed them as unwanted but necessary outcomes of the state's fight against terrorism.

At the height of the forest fires in Dersim, Sözcü published an interview with Tunceli Governor Tuncay Sonel, who at the time of the interview was acting as the appointed trustee of the Dersim municipality. ${ }^{6}$ The interview included a photograph in which Governor Sonel enjoys a cup of tea in Aliboğazı, a region that is often listed as a forbidden military zone due to security threats for the military. As we note in the discussion

\footnotetext{
$\overline{5}$ In the summer of 2016, Özgür Gündem was closed down by the court in Turkey under charges of "[terrorist] organisation propaganda." The newspaper continued after 2018 with a new name, Özgür Yaşam. This reflects the suppression of Kurdish media in the post-2015 period, which is why there was no news coverage from pro-Kurdish newspapers in 2016 and 2017. These two newspapers are grouped together in the analysis.

${ }^{6}$ In the aftermath of the peace process and the failed "coup attempt" on 15 July 2016, political oppression of the Kurdish municipalities increased, leading to over 100 elected mayors and municipality officers of the pro-Kurdish political parties HDP and BDP (Peace and Democracy Party) being replaced by appointed trustees.
}

below, Aliboğazı was one of the places where repeated forest fires in times of conflict in Dersim occurred (Sözcü, 24 August 2018). The interview completely ignored the ongoing forest fires in the region as well as the protests of the local people, attempting to symbolically show that the state and its army were taking control of the region and "conquering" the zones once controlled by the "terrorists."

In contrast, left-wing and pro-Kurdish newspapers published numerous articles on the forest fires in Dersim. Of these, Cumhuriyet was the only one that referred to the province as Tunceli - the others used Dersim in their content. There was an increasing number of news pieces published in Birgün, Cumhuriyet, Evrensel, Özgür Gündem, and Yeni Yaşam (Fig. 3). The most frequently used words in the titles of the news articles in selected newspapers included "Dersim", "fire" [yangin], "burning" [yanıyor], "state" [devlet], "intervention" [müdahale], and "absent" [yok] (Fig. 4).

With increasing authoritarianism under the AKP government following the failed peace process in 2015 and the alleged "coup attempt" in 2016 (Sözen 2020; Erensü and Alemdaroğlu 2018; Tansel 2018), media in Turkey has suffered intensifying political pressure, financial sanctions, bans of media outlets, as well as imprisonment of media employees (Yildirım et al. 2020). In these circumstances, social media have become an important tool for receiving and disseminating information. Twitter in particular has been an important platform for different accounts of forest fires in Dersim. Approximately 15,000 tweets (including original tweets but excluding retweets) addressing the forest fires in Dersim were shared with selected hashtags between 2015 and 2018, with almost all tweeted in August (Fig. 5). The number of tweets about forest fires in Dersim typically increases in August, when most of the forest fires take place. The word cloud of these tweets on the one hand shows words that reflect the criticism toward the state for either ignoring the forest fires or for lack of action in extinguishing the fires, such as "Dersim", "tree" [ağaç], "forest" [orman], "fire" [yangın, also ateş], "silence" [sessizlik], and "state" [devlet] (Fig. 6). On the other hand, we see Tunceli, the "PKK," "God" [Allah], "terrorists" [terrorist], and "Turk," indicating support of the state approach, referring to the "terrorist activities" taking place in the region that the state claimed to be rightfully fighting against. According to this view, even if the state's struggle against "terrorism" meant there would be some loss of forests or tree cover, the well-being and security of the nation should be prioritised.

Looking at the history of the Turkish state and its military campaign against the PKK, local residents suspected that the state had returned to its forest burning and evacuation strategy in the aftermath of the failed peace process. Local testimonies often highlighted that forests in Dersim were set on fire as a result of soldiers firing explosives and possibly howitzers 
Fig. 2 The number of news reports about forest fires in Dersim in August of 2015-2018 by newspaper

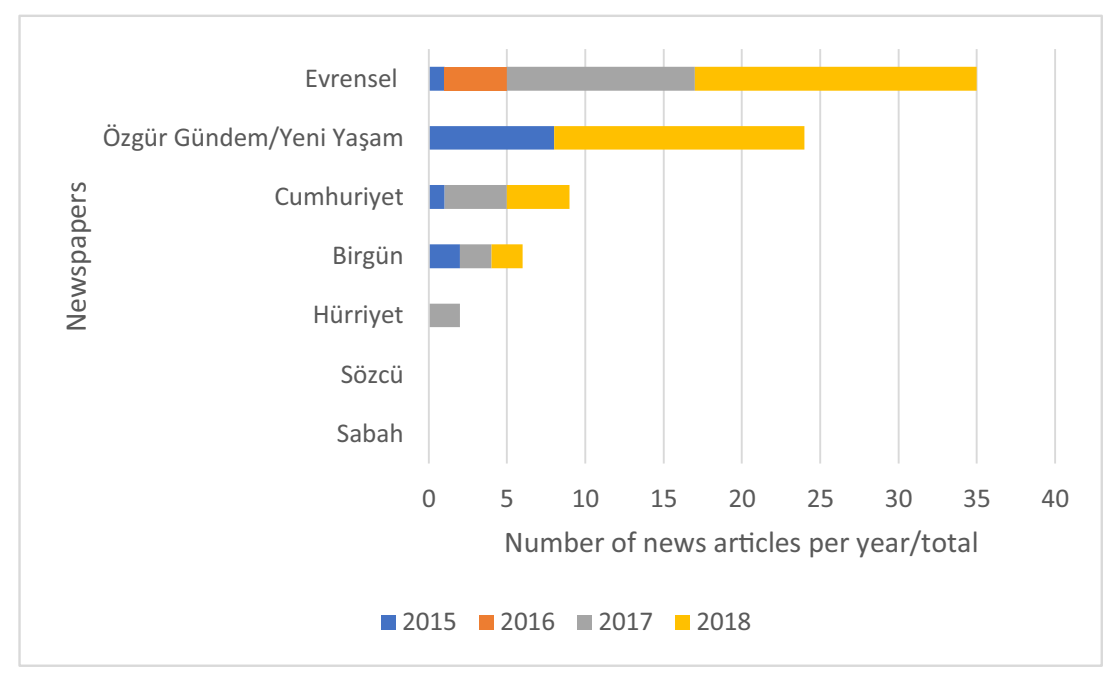

from police stations (DTK Report 2015; Fig. 7). Local people also claimed that the military dropped bombs from combat helicopters on the grounds that the army had "images of terrorist activity in the area." A report on forest fires in Dersim in 2017-2018 prepared by the Centre for Dersim Studies also stated that the majority of forest fires in the region were caused by air bombardments and attacks commenced from military strongholds. The local informants added that forest fires would also take place around the kulekols (military strongholds situated on the top of hills) because the security officers want a clearer view of the surrounding area. Another common opinion cited by the local community is that the Turkish state has long been aiming to bring about demographic change in Dersim, by sending local Dersimlis away and opening the area for mining and energy companies. The statements issued by the local government, however, deny such allegations and describe them as "fake news." A statement issued by the
Tunceli Governorship in 2018 read: "This kind of news is deliberately made by some segments and it is designed to cast a shadow over our city of peace, Tunceli" (Basın Açıklaması 2018).

Although we are not suggesting a causal relationship between forest fires and conflict in Dersim, we believe these local accounts provide an important insight into the differences between the narratives of the state and the local people.

\section{Verifying the Narratives: A Quantitative Assessment of Conflict and Fires}

Our assessments of the existing narratives show the contested nature of forest fires in Dersim. We conducted a quantitative assessment to account for fires in Dersim, evaluated the fires within the context of conflict and political instability, and
Fig. 3 The number of news reports on forest fires in Dersim during August 2015-2018

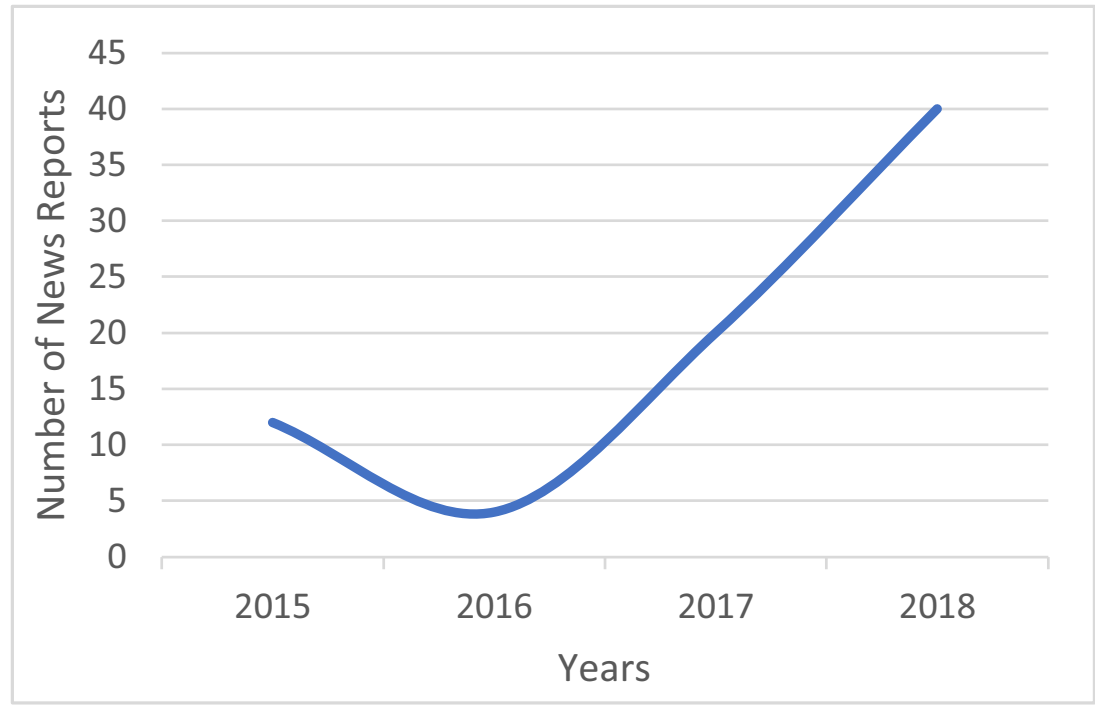




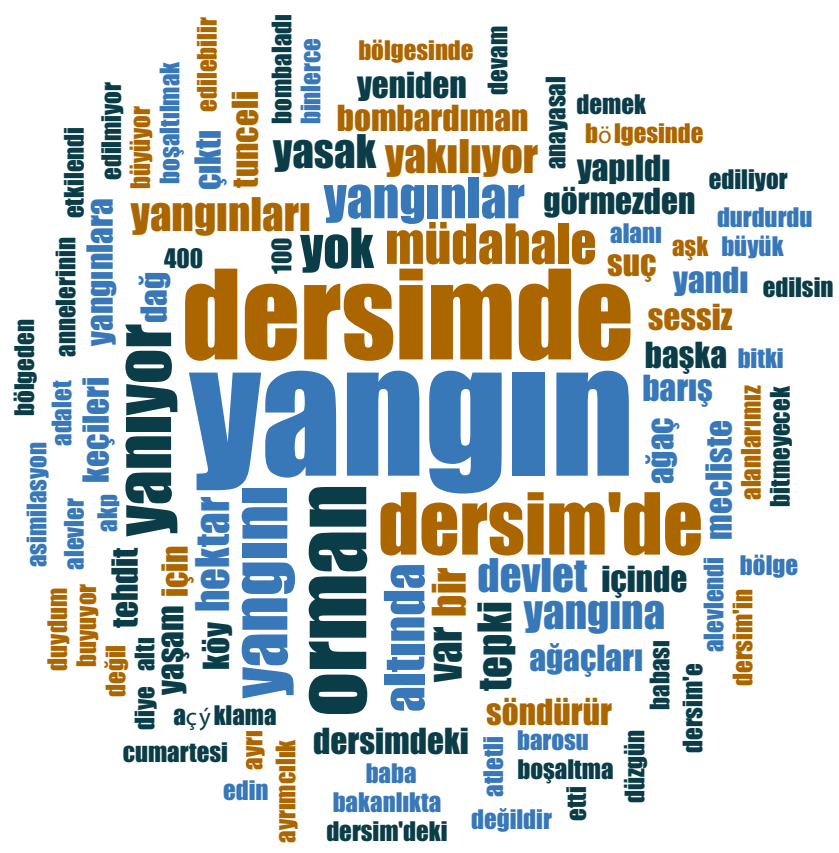

Fig. 4 Word cloud showing the most frequently used words in titles of news articles published during August of 2015-2018

determined the statistical relationship between the number of fires and the number of conflicts in the area. According to the UCDP, 94\% of conflicts in Turkey from 2003 to 2019 were between the Turkish government and the PKK. The assessment shows that the conflict data are reflective of the political context from the early 2000s and onwards. In Dersim, the number of fires increases after 2014 (Fig. 8) and statistically significant correlations between the conflict and fire data are found for Dersim.

Between 2003 and 2019, the frequencies of both conflict and fires in Dersim have fluctuated (Fig. 8). The number of conflicts recorded was highest in 2004 (25) while the fire count was low. However, after 2006, conflict and fire occurrences seem to follow a similar pattern, both locally (Dersim) and on a national scale (Turkey). One noticeable trend in Turkey's conflict data is the decrease in conflict in 2013, marking the start of the peace process, followed by the considerable increase in conflict in 2015, marking the collapse of the peace process. From 2015 onwards, the number of fires increased and reached a peak in 2017, with 38 recorded fires in Dersim. These data thus confirm narratives about a dramatic increase in forest fires after the end of the peace process in 2015. The number of conflict events in Dersim remained comparatively low until 2018, but conflict events recorded in Turkey as a whole reflect this increase in violence after the end of the peace process.

The results of the Spearman-Rank test show a statistically significant and positive moderate relationship $\left(r_{s}=0.51, p\right.$ value $=0.05$ ) between the fires in Dersim and the conflict events in Turkey. This association indicates that accounts of fires in Dersim and national-scale conflict dynamics, to a moderate degree, increase and decrease simultaneously.

The bivariate local relationship between the conflicts and fires for Tunceli (Dersim) province before and after 2015 shows that few areas have a high number of fires in the neighbourhood of high conflict and vice versa (Fig. 9, HighHigh); High-Low shows areas of a high number of fires in the neighbourhood of low conflict, and corresponding explanations are valid for Low-Low and Low-High clusters. Analysing the temporal trends of High-High clusters shows that there was a reduction in their number (from five to one) over time. A neighbourhood is defined as five kilometres surrounding the grid cells where the occurrences (fires or conflicts) occured.

Between 2003 and 2019, the climate was generally drier than normal, with three years showing values below -3 , indicating severe to extreme drought (Fig. 10). The PDSI values for August generally follow the pattern of the full-year PDSI.
Fig. 5 The number of tweets on forest fires in Dersim during August of 2015-2018

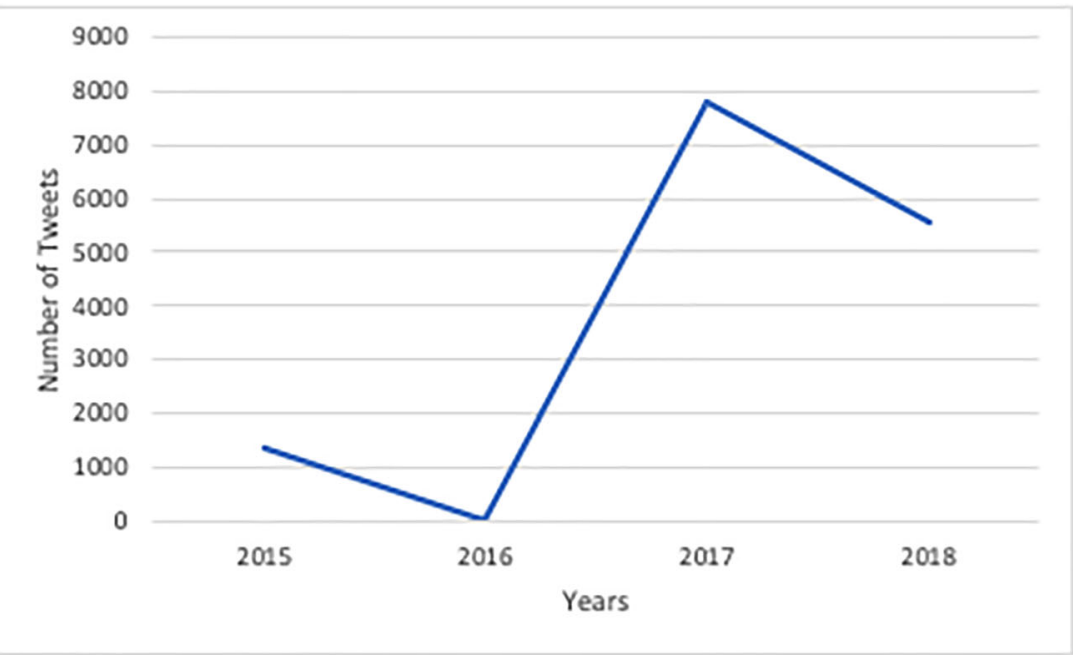


Fig. 6 Word cloud showing most frequently used words in tweets

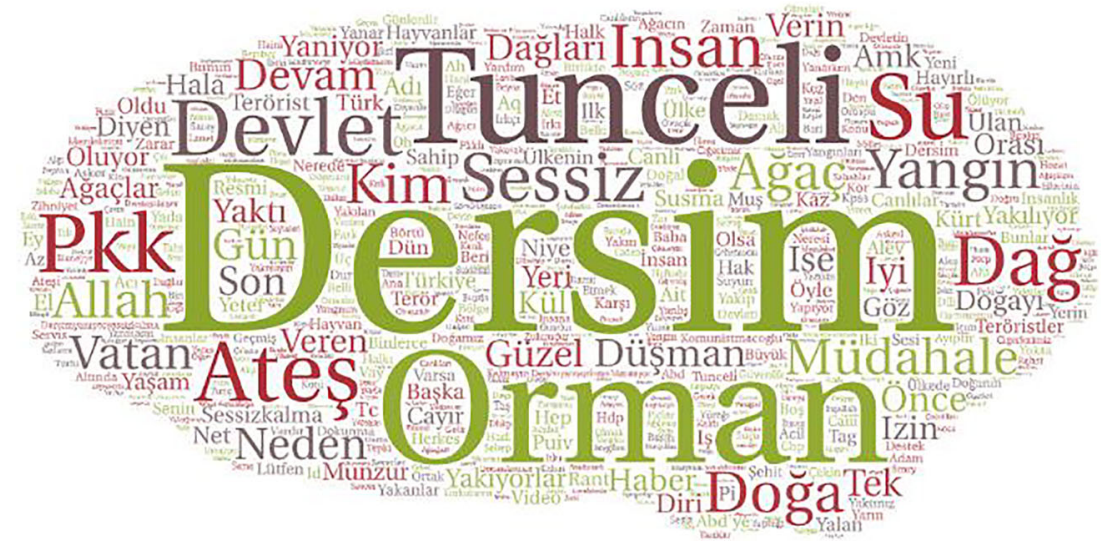

The driest years were 2008, 2014, and 2017, and while the dry spell in 2017 corresponds with the highest number of fire events for the whole period, few fire events were recorded in 2008 and 2014.

\section{Discussion}

Statistical analysis suggests a significant relationship between fires and conflicts in Dersim, showing that as the number of conflicts (in Turkey) increases or decreases, the number of fires generally follows. While no strong increase in violence was recorded in Dersim directly after 2015, the situation in other parts of Turkey reflects a period of increased conflict as well as increases in forest fires. As noted above, the strict definition of conflict in the dataset may mean that tensions or conflicts in Dersim were not recorded due to zero fatalities.

It is important to note that there are other causes of fire aside from conflict. Dry summers with high temperatures and low precipitation often come with an increase in wildfires and may act as a catalyst for human-caused fires (Ganteaume et al. 2013; Bowman et al. 2009). Fires are caused by a multitude of factors, both natural (e.g., lightning or drought) and human-made (accidents, agricultural practices, or arson). Dry

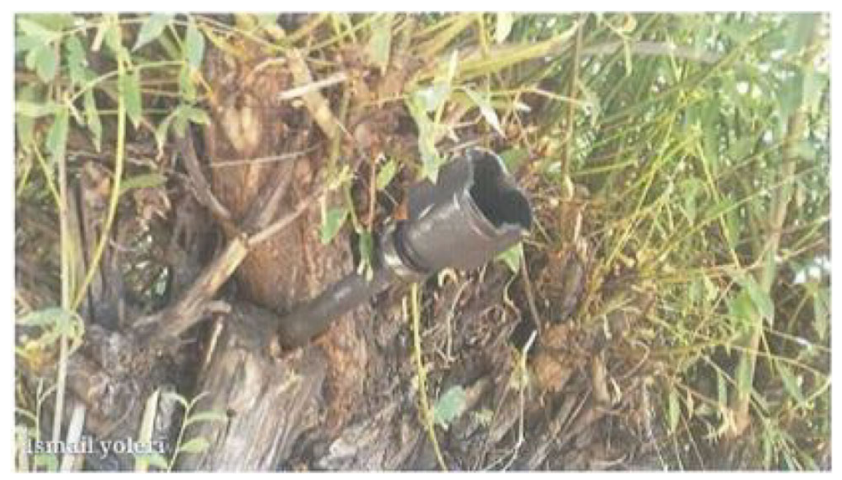

Fig. 7 Military equipment found by the Munzur Association to Protect Natural Life in the fire area in Dersim, which was suspected as the likely cause of the forest fire. Source: DTK Report, 2015 weather, as an effect of climate variability or anthropogenic climate change, is expected to increase the risk of fires. Our dryness and fire data, however, show few indications of a strong relationship for Dersim. We find that not all dry years have a high number of fires recorded, and the years with many fires are not all dry years. This suggests that while climate is one aspect of fire risk, other factors, such as conflict, likely play a role in the increase in fires from 2015 and onwards.

The Bivariate Local Indicators of Spatial Association analysis shows that in certain areas within Dersim there are HighHigh clusters of conflict and fire. These places, namely Hozat (Aliboğazı), the Munzur Valley, Bali, Kutuderesi, and Geyiksuyu, also happen to have been marked as "Temporary Military Security Zones" over the years, which bans civilian entry. This detail rules out the human-made factors caused by civilians in the region, such as accidents, agricultural practices, or arson. In other words, the quantitative analysis of fires and conflict in Dersim indicates that the narratives we found through the content analysis of newspapers, social media posts, reports of civil society organisations and political parties, and testimonies of the local people are supported.

The content of news articles, and the tweets that drew attention to the allegedly state-set forest fires in Dersim, focused on four main points. The first was that these fires were set intentionally by the state, often as a result of air bombardment. News titles read "Bombardment in Dersim: the fires reignited," or "Bombardment to Dersim that was burning," and tweets read "Dersim is not on fire, they are burning it," and "Kurdistan is being burned down." The second point was that once the fires began, the state was failing to fight them by deliberately not using its fire fighting vehicles and blocking civilians who wanted to put the fires out. The newspapers also reported that the ministry had no reports of forest fires in Dersim and the state deliberately ignored them, that there was no firefighting by the state authorities, and that civilians were not allowed to enter these regions to extinguish the fires because they were "Temporary Military Security Zones." The third point was the repetition of forest fires as a state strategy 
Fig. 8 The number of fire and conflict events recorded by MODIS (fire) and UCDP (conflict) in Dersim and Turkey as a whole (conflict events, secondary axis) between 2003 and 2019 (annual)

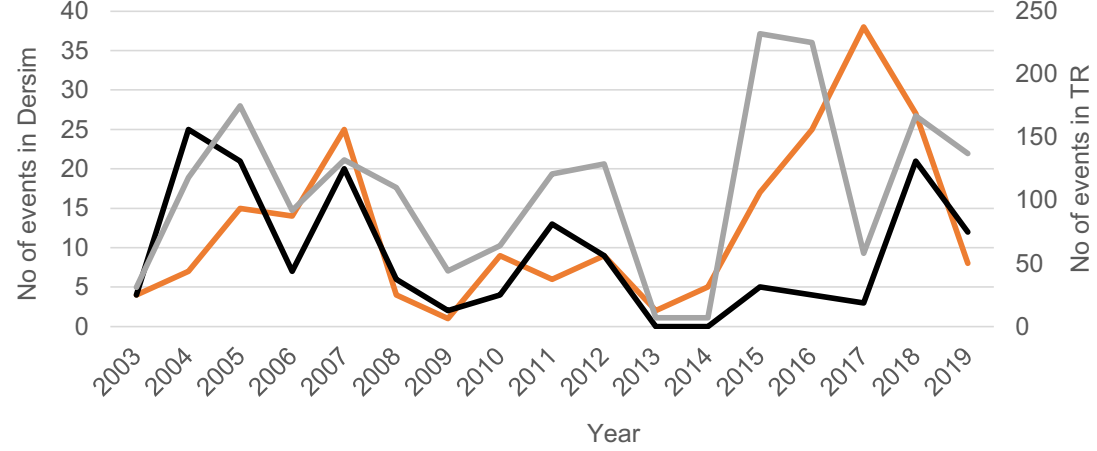

—Fire Dersim —Conflict Dersim —Conflict Turkey (plotted on secondary axis) in the region, often making a connection between the forest fires and forced village evacuations in Dersim in the 1990s. There were references to the destruction of life and trees in Kurdistan, the repeated instances of forest fires in Dersim, and arguments that peace was the only way to stop these fires. There were also frequent references to the forest fires and forced village evacuations on Twitter. Last but not least, these news articles and tweets regularly highlighted that forest fires were causing harm to Dersim's people, animals, and natural environment, which are seen as sacred in the local belief system and culture. The news articles referred to sacred places (e.g., Düzgün Baba) and animals (e.g., mountain goats) that were under threat, and that it was not only Dersim's natural environment but also its beliefs and culture that was being burned down.

The local accounts shared in reports and with us directly argue that the number of forest fires increased dramatically after the end of the peace process in the summer of 2015 ,
Fig. 9 Bivariate Local Indicators of Spatial Association [20032014 (a) and 2015-2019 (b)]. Map of Dersim Study Area shown above

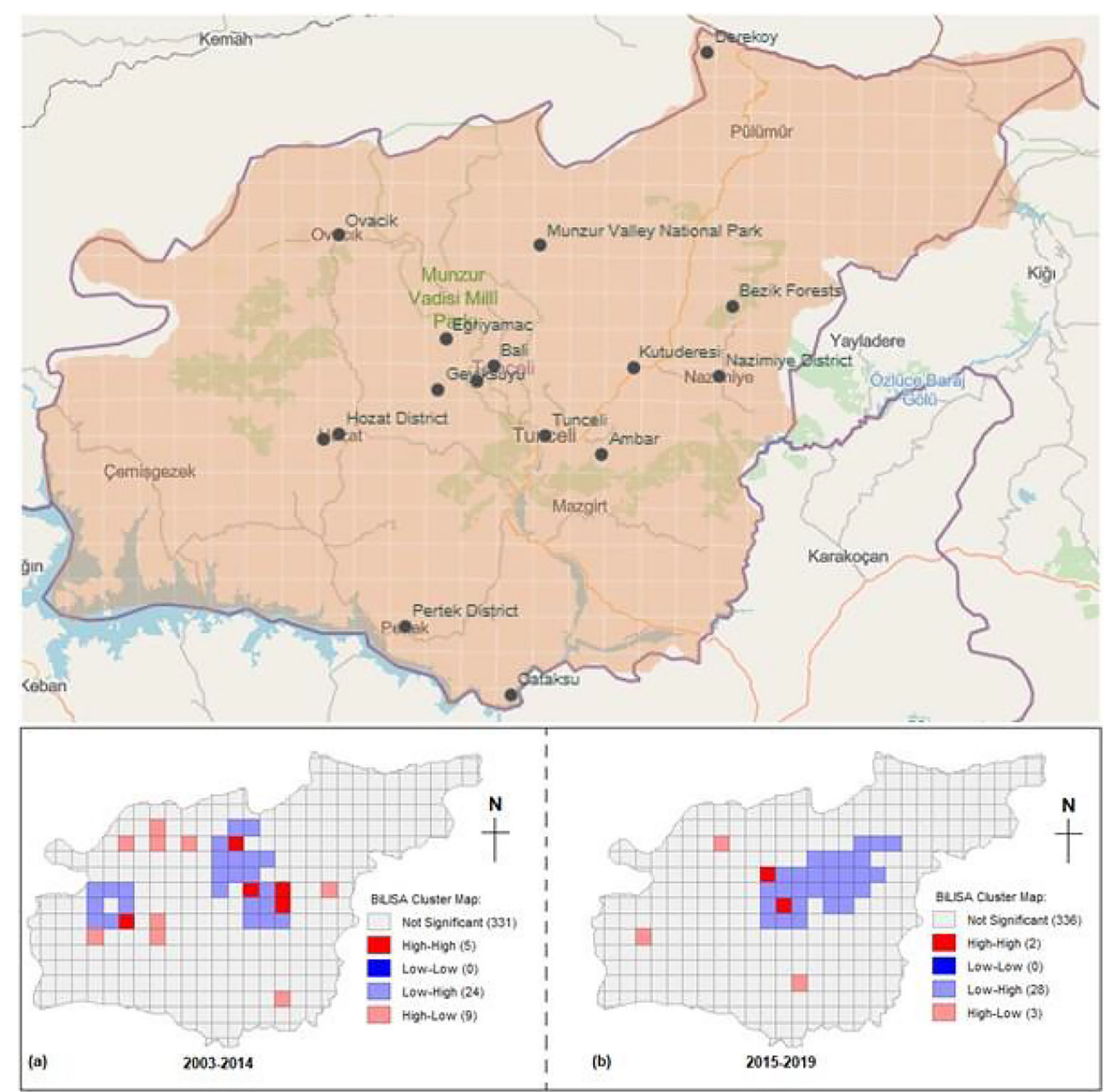


Fig. 10 Dryness as represented by The Palmer Severity Drought Index (PDSI) for the years 2003 2019, plotted together with the number of fire events for all years and for August

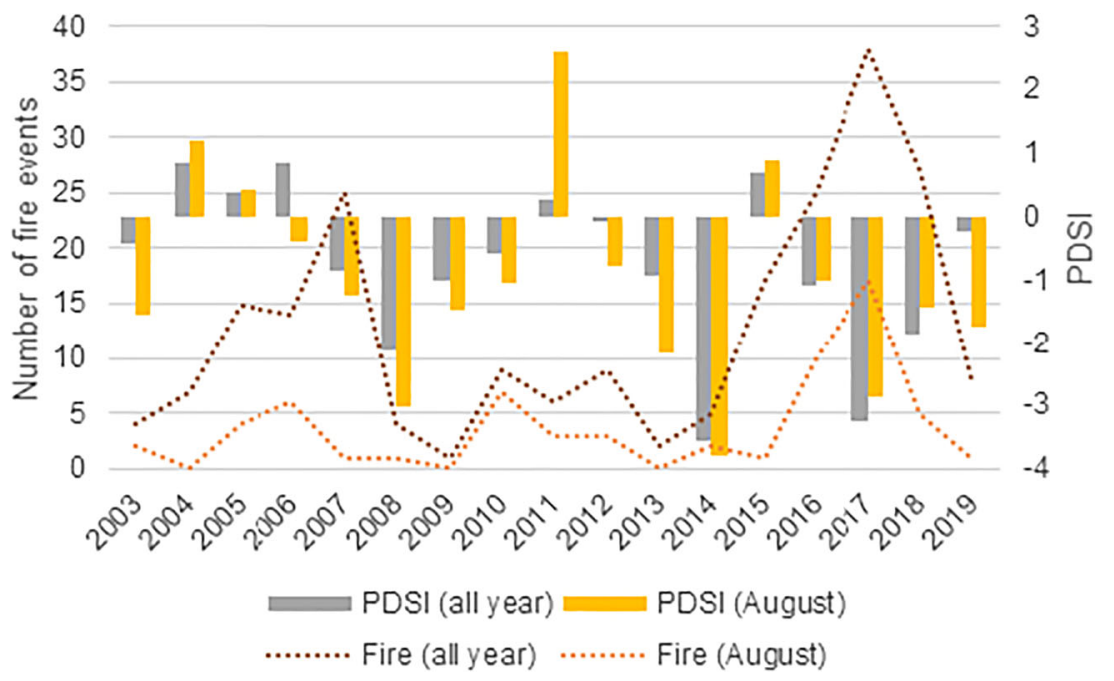

which is supported by the fire data. Dersimlis often stated that intentional fire burning in their region is nothing new, and they often referred back to the period of the Ottoman Empire when Dersim was viewed as a backward, rebellious community to be disciplined with different military measures. They also had fresh memories of the traumatic 1993-94 burning and forced evacuation of Dersim's forests and villages. They argued that news articles and social media campaigns help others become aware of the environmental damage in Dersim, since the state is often dishonest when it comes to sharing information about the forest fires. One of our respondents in Dersim noted that "the state sets the forest on fire every other year, they don't let the trees grow. As soon as the trees are as tall as a human being, they set another fire." They also accuse civil society organisations and environmental groups of ignoring the environmental damage in Dersim, occurring not only through forest fires but also as a result of dam projects and mining activities initiated by the state.

\section{Conclusion}

Our discussion of the conflict and forest fire nexus in Dersim addresses two main issues in the field. First, we show how interdisciplinary analysis combining quantitative datasets with in-depth, qualitative data allows a better understanding of the geopolitics of fire. Although we cannot always determine the causes of fire, qualitative research methods combined with quantitative data allow us to investigate whether there is a positive relationship between conflict and forest fires. For the case of Dersim, we were able to conclude that the number of forest fires in the area has indeed increased in the aftermath of the failed peace process between the Turkish state and the PKK.

Second, and more importantly, our analysis allows us to examine whether and how forest fires can be politicised in the sense that the insurgent/oppressed groups accuse the power holders (i.e., the state) of deliberately damaging the environment to establish their domination and hegemony. We focused on a single case study, but Dersim is by no means the only region in Turkey where conflict and forest fires are allegedly interrelated. Other provinces in Turkey's Kurdistan, such as Diyarbakır, Hakkari, and Şırnak (Dinç, forthcoming 2021), as well as Iraqi Kurdistan (Eklund et al. 2021) have similarly indicated that forest fires and conflict are connected. Other cases in various parts of the world should also be investigated to generate knowledge about environmental damage in conflict contexts. Such analyses would contribute to the field and provide a better understanding of the geopolitics of fire.

Funding Open access funding provided by Lund University. The FIRE project leading to these results received funding from the European Union's Horizon 2020 research and innovation programme under the Marie Sklodowska-Curie Grant, Grant Agreement No 796086.

\section{Declarations}

Informed Consent The FIRE Project (Grant Agreement No 796086) has an ethical approval from the Swedish Ethical Review Authority (2019).

Conflict of Interest The authors have no relevant financial or nonfinancial interests to disclose.

Open Access This article is licensed under a Creative Commons Attribution 4.0 International License, which permits use, sharing, adaptation, distribution and reproduction in any medium or format, as long as you give appropriate credit to the original author(s) and the source, provide a link to the Creative Commons licence, and indicate if changes were made. The images or other third party material in this article are included in the article's Creative Commons licence, unless indicated otherwise in a credit line to the material. If material is not included in the article's Creative Commons licence and your intended use is not permitted by statutory regulation or exceeds the permitted use, you will need to obtain permission directly from the copyright holder. To view a copy of this licence, visit http://creativecommons.org/licenses/by/4.0/. 


\section{References}

Abatzoglou, J., Dobrowski, S., Parks, S. et al. (2018) 'TerraClimate, a high-resolution global dataset of monthly climate and climatic water balance from 1958-2015'. Sci Data 5, 170191

Algör, İ. (Ed.). (2010) Ma Sekerdo Kardaş? N'etmişiz kardaş? “Dersim 38" Taniklıkları. İstanbul: Doğan Kitap.

Al Jazeera (2011) 'Erdogan apologises to Kurds for mass killing'. https:// www.aljazeera.com/news/2011/11/24/erdogan-apologises-tokurds-for-mass-killing. Accessed 12 April 2021.

Alpkaya, F. H. (1988) Cumhuriyet Rejiminin Bir Islah Çalışması. İstanbul Üniversitesi Sosyal Bilimler Enstitüsü Siyaset Bilimi Anabilim Dalı Yüksek Lisans Tezi (unpublished thesis).

Aras, B., \& Polat, R.K. (2008) 'From Conflict to Cooperation: Desecuritization of Turkey's Relations with Syria and Iran'. Security Dialogue 39, no. 5: 495-515.

Austin, J. \& Bruch, C. (2000) The Environmental Consequences of War: Legal, Economic, and Scientific Perspectives. Cambridge, New York: Cambridge University Press.

Baser, B. \& Ozerdem, A. (2019) 'Conflict Transformation and Asymmetric Conflicts: A Critique of the Failed Turkish-Kurdish Peace Process'. Terrorism and Political Violence: 1-22.

Basın Açıklaması (2018) http://www.tunceli.gov.tr/basin-aciklamasi1212. Accessed 4 August 2020

Basın Açıklaması (2017) http://www.tunceli.gov.tr/basinaciklamasi11082017. Accessed 4 August 2020.

Beşikçi, İ. (2013) Tunceli Kanunu (1935) ve Dersim Jenosidi. İstanbul: İBV Roni Yayınları.

Bilmez, B., Kayacan, G., \& Aslan, Ș.. (2011) Toplumsal bellek, kuşaklararası aktarım ve algl: Dersim '38' i hatırlamak. İstanbul: Tarih Vakfi Yurt Yayınları.

Bowman, D.M.J.S., Balch, J.K., Artaxo, P., Bond, W.J., Carlson, J.M., Cochrane, M.A., D'Antonio, C.M., et al. (2009) 'Fire in the Earth System'. Science 324, no. 5926: 481.

Bruinessen, M. (1997) 'Aslını inkar eden haramzadedir: The debate on the ethnic identity of the Kurdish Alevis.' In K. Kehl-Bodrogi, B. Kellner-Heinkele \& A. Otter-Beaujean (Eds.), Syncretistic Religious Communities in the Near East (pp. 1-23). Leiden: Brill.

Bulut, F. (2013) Dersim Raporları. İstanbul: Evrensel Basın Yayın.

Çalıșlar, İ. (Ed.). (2010) Dersim Raporu. İstanbul: İletișim Yayınları.

Çiçek, C. (2018) 'Süreç' Kürt Çatışması ve Çözüm Arayışları. İstanbul: İletişism Yayınları.

Dai, A. \& National Center for Atmospheric Research Staff (Eds). Last modified 12 (2019). 'The Climate Data Guide: Palmer Drought Severity Index (PDSI).' Retrieved from https://climatedataguide. ucar.edu/climate-data/palmer-drought-severity-index-pdsi.

Deniz, D. (2020) 'Re-assessing the Genocide of Kurdish Alevis in Dersim, 1937-38." Genocide Studies and Prevention: An International Journal, 14 no. 2: 20-43.

Dicle, A. (2017) 2005-2015 TÜRKIYE-PKK GÖRÜSSMELERİ: Kürt Sorununun Ç̈zzümüne 'çözüm Süreci' Operasyonu. Neuss: Mezopotamya Yayınları.

Dinc, P. (2021) 'Forest fires in Dersim and Șirnak: Conflict and Environmental Destruction'. In Stephen E. Hunt (ed), Kurdish Ecology: Environmental Thought, Challenges and Activism. Lexington Books [forthcoming].

Dinç, P. (2020a) 'Euro-Who? Competition over the Definition of Dersim's Collective Identity in Turkey's Diasporas'. Turkish Studies 1-25.

Dinc, P. (2020) 'The Kurdish Movement and the Democratic Federation of Northern Syria: An Alternative to the (Nation-)State Model?' Journal of Balkan and Near Eastern Studies 22, no. 1: 47-67.

Dinc, P. (2020b). 'Cözüm Süreci Sonrası Dersim'de Orman Yangınları ve Çatışma İlișkisi'. Birikim, 378: 109-120.
Eklund, L., Abdi, A.M., Shahpurwala, A., Dinc, P. (2021). "On the Geopolitics of Fire, Conflict and Land in the Kurdistan Region of Iraq" Remote Sens. 13, no. 8: 1575.

Erensü, S. \& Alemdaroğlu, A. (2018) 'Dialectics of Reform and Repression: Unpacking Turkey's Authoritarian "Turn"”. Review of Middle East Studies, 52 no. 1: 16-28.

Etten, J. Van, Jongerden, J, de Vos, H.J., Klaasse, A., and van Hoeve, E.C.E. (2008) 'Environmental Destruction as a Counterinsurgency Strategy in the Kurdistan Region of Turkey'. Geoforum 39, no. 5: 1786-97. https://doi.org/10.1016/j.geoforum.2008.05.001.

Ganteaume, A., Camia, A., Jappiot, M., San-Miguel-Ayanz, J., LongFournel, M., and Lampin, C. (2013) 'A Review of the Main Driving Factors of Forest Fire Ignition Over Europe'. Environmental Management 51, no. 3: 651-62.

Giglio, L., Schroeder, W., and Justice, C.O. (2016) 'The Collection 6 MODIS Active Fire Detection Algorithm and Fire Products'. Remote Sensing of Environment 178: 31-41.

Goner, O. (2017) Turkish National Identity and Its Outsiders Memories of State Violence in Dersim . Oxon, UK : Routledge.

Gurses, M. (2012) 'Environmental Consequences of Civil War: Evidence from the Kurdish Conflict in Turkey'. Civil Wars 14, no. 2: 254-71. https://doi.org/10.1080/13698249.2012.679495.

Hough, P. (2014) "The Spoils of War: Military Security and the Environment." In Environmental Security, 73-85. Routledge.

Jongerden, J., de Vos, H., \& van Etten, J. (2007) 'Forest Burning as Counterinsurgency in Turkish-Kurdistan: An Analysis from Space'. The International Journal of Kurdish Studies 21, no. 1 \& 2: $1-16$.

Jongerden, J. (2019) 'Conquering the State and Subordinating Society under AKP Rule: A Kurdish Perspective on the Development of a New Autocracy in Turkey'. Journal of Balkan and Near Eastern Studies 21, no. 3: 260-73.

Kaya, Z., \& Whiting, M. (2017) 'Sowing Division: Kurds in the Syrian War'. Middle East Policy 24, no 1: 79-91.

Kehl-Bodrogi, K. (1999) 'Kurds, Turks, or a people in their own right? Competing collective identities among the Zazas.' The Muslim World 89 no. 3-4: 439-454.

Keiser, H. (2011) 'DersimMassacre, 1937-1938'. Online Encyclopedia of Mass Violence, [online] 2011. http://www.sciencespo.fr/massviolence-war-massacre-resistance/fr/node/ 3014 .

Levene, M. (2005) 'Genocide in the Age of the Nation-State Volume I: The Meaning of Genocide'. New York, I.B. Tauris.

Martini, E.A. (2013) Hearts, Minds, and Herbicides. Diplomatic history, 37 no.1: $58-84$.

Nguyen, T.T. (2009) "Environmental Consequences of Dioxin from the War in Vietnam: What Has Been Done and What Else Could Be Done?" International Journal of Environmental Studies 66, no. 1: 926.

Öcalan, A. (2011) Democratic Confederalism, Transmedia Publishing and Cologne: International Initiative Edition, London.

Question for written answer E-005396/2018. (2020) https://www. europarl.europa.eu/doceo/document/E-8-2018-005396_EN.html. Accessed 4 August 2020.

Shahpurwala, A. (2019) 'Conflict, Narratives, and Forest Fires in Eastern Turkey. A Quantitative Perspective with Remote Sensing and GIS' MS Thesis, Lund University. http://lup.lub.lu.se/luur/download? func $=$ downloadFile \&recordOId $=8989478 \&$ fileOId $=8990219$.

Sözen, Ü. (2019) "Culture, Politics and Contested Identity among the 'Kurdish' Alevis of Dersim: The Case of the Munzur Culture and Nature Festival." Journal of Ethnic and Cultural Studies 6, no. 1: 63-76.

Sözen, Y. (2020) 'Popular Will against Democracy: Populist Autocratization in Turkey'. Reflektif Journal of Social Sciences 1no. 1: 9-30. 
Spearman, C. “"General Intelligence," Objectively Determined and Measured'. The American Journal of Psychology 15, no. 2 (1904): 201-92.

Sundberg, R., \& Melander, E. (2013) 'Introducing the UCDP Georeferenced Event Dataset'. Journal of Peace Research 50, no. 4: $523-32$.

Tansel, C.B. (2018) 'Authoritarian Neoliberalism and Democratic Backsliding in Turkey: Beyond the Narratives of Progress'. South European Society and Politics 23 no. 2: 197-217.

Taș, C. (2007) Külden Evler: Dersim'de Yakılan Köylerin Öyküsü. İstanbul: Tij.

Ünal, M.C. (2016) 'Is It Ripe yet? Resolving Turkey's 30 Years of Conflict with the PKK'. Turkish Studies 17, no. 1: 91-125.

Yıldırım, K., Baruh, L. \& Çarkoğlu, A. (2020) 'Dynamics of Campaign Reporting and Press-Party Parallelism: Rise of Competitive Authoritarianism and the Media System in Turkey' Political Communication.

Y1ldız, M. (2014) Dersim'in Etno-Kültürel Kimliği ve 1937-1938 Tertelesi. İstanbul: Chiviyazıları Yayınevi.

\section{Newspapers}

Hürriyet, (2015), 2016, 2017, 2018

Sözcü, (2015), 2016, 2017, 2018

Sabah, (2015), 2016, 2017, 2018

Cumhuriyet, (2015), 2016, 2017, 2018

Evrensel, (2015), 2016, 2017, 2018

Birgün, (2015), 2016, 2017, 2018
Özgür Gündem, (2015).

Yeni Yașam, (2018).

\section{Reports}

CHP Report, (2015) 'Dersim'de Yaşanan Orman Yangıları ile İlgili Gözlem Raporu', August 2015, personal archive.

DAM Report (2019) 'Dersim 2017-2018 Orman Yang1lar1 Raporu', June 2019, personal archive.

DTK Report, (2015) 'Amed (Diyarbakır) Lice, Fis Ovası-Kulp Bitlis (Bedlis), Norșin-Șeyh Cuma, Dersim (Tunceli)-Bingöl Yayladere, Botan Bölgesi, Cudi-Nusaybin-Siirt-Eruh-Șırnak-Silopi Orman Yangınları Araștırma, İnceleme ve Gözlem Raporu'. https://www. mezopotamyaekoloji.org/wp-content/uploads/2017/05/OrmanYang\%C4\%B1nlar\%C4\%B1-Raporu.pdf. Accessed 4 August 2020.

HDP Report, (2015) 'Savaș Stratejisi'nin Bir Uzantısı Olarak Orman Yangınları: Temmuz-Ağustos 2015'te Kürdistan'daki Orman Yangınlarına İlișkin Gözlemler ve Teknik İleme Raporu', 21 August 2015, https://yesilgazete.org/wp-content/uploads/2015/08/ Temmuz-\%E2\%80\%93-A\%C4\%9Futos-2015\%E2\%80\%99te-K\% C3\%BCrdistan\%E2\%80\%99daki-Orman-Yang\%C4\%B1nlar\% C4\%B1na-\%C4\%B0li\%C5\%9Fkin-G\%C3\%B6zlemler-veTeknik-\%C4\%B0nceleme-Raporu-\%E2\%80\%93-Sava\%C5\%9FStratejisi\%E2\%80\%99nin-Bir-Uzant\%C4\%B1s\%C4\%B1-OlarakOrman-Yang\%C4\%B1nlar\%C4\%B1.pdf, accessed on 4 August 2020.

Publisher's Note Springer Nature remains neutral with regard to jurisdictional claims in published maps and institutional affiliations. 